\title{
A Proposal to Restructure Sanctions Under the Occupational Safety and Health Act: The Limitations of Punishment and Culpability
}

The Occupational Safety and Health Administration (OSHA) is the federal agency charged with setting and enforcing standards under the Occupational Safety and Health Act of 1970 (OSHAct). ${ }^{1}$ The typical response available to OSHA for the vast majority of violations of the Act is the post-hoc civil citation and fine. Both the framers of the OSHAct and subsequent critics, however, have realized that in some situations extraordinary measures are necessary. It is upon those extraordinary measures that this Note focuses. The Note argues that the most severe sanctions and remedies established in the OSHAct, and the circumstances under which they are imposed, are poorly suited to affecting the behavior of the most dangerous employers. The primary failures of the Act addressed here are 1) that the criminal sanction, included in the Act as the supposed "big gun" of the enforcement arsenal, is inherently ineffective in this regulatory context; 2) that the Act's civil enforcement provisions are too weak and narrow to effect OSHA's statutory mandate; and 3) that the emphasis in the Act on "willful" and lethal violations as the most seriously sanctioned violations is inappropriate. In response to these problems, the Note advocates giving OSHA the power to issue broad orders imposing prospective safety programs on particularly recidivous employers.

\section{A Brief Description of the Gurrent Statutory Sanctions and Remedies}

The OSHAct authorizes OSHA to promulgate specific standards of industrial safety. ${ }^{2}$ Through a system of on-site inspections, OSHA enforces those specific standards as well as the "general duty" of employers to provide a safe workplace. ${ }^{3}$ Inspectors are empowered to issue a range of citations for violations, which can carry either civil or criminal penalties. ${ }^{4}$

1. 29 U.S.C. $\S \S 651-78$ (1976 \& Supp. 1980). OSHA is an agency within the Department of Labor.

2. 29 U.S.C. $\S 655$ (1976).

3. 29 U.S.C. $\S \S 657-58$ (1976) (establishing procedures for inspection and citation). See also 29 U.S.C. $\S 654$ (1976) (establishing duties of employers).

4. See 29 U.S.G. § 666 (1976) (describing possible citations). If an employer chooses to contest a civil citation, the employer is entitled to formal adjudicatory proceedings before the Occupational Safety and Health Review Commission (OSHRC), an adjudicatory federal agency extrinsic to the Department of Labor. 29 U.S.C. $\S 659$ (c) (1976). Initial hearings are before an administrative law 
Section 666 of the OSHAct contains a collection of criteria by which violations are divided hierarchically into classes. "Serious" violations are distingushed from "non-serious" violations by the presence of a "substantial probability that death or serious physical harm could result." Unless a violation is explicitly cited as "willful or repeated," it carries a maximum penalty of a $\$ 1000$ civil fine. "Willful or repeated" violations, the most seriously sanctioned class of civil violations, carry a civil fine of up to $\$ 10,000$ each. ${ }^{7}$ Criminal penalties are available under the Act only when a violation is "willfully" committed, and "cause[s] death to any employee." The maximum criminal penalties are a $\$ 10,000$ fine, six months in prison, or both.'

OSHA's power to require particular prospective remedies takes two forms. When OSHA cites any violation, it is empowered to "fix a reasonable time for the abatement of the violation."10 If this "abatement order" is not satisfied within the fixed time, OSHA may issue an additional citation for failure to correct. " Such "abatement violations" can carry a fine of up to $\$ 1000$ per day. OSHA policy generally limits the overall fine to ten times the daily penalty, again resulting in a $\$ 10,000$ maximum fine. ${ }^{12}$ OSHA's second prospective remedial power is its ability to seek temporary restraining orders and injunctions to avert any "imminent danger."13 The courts and the Occupational Safety and Health Review Commission (OSHRC), ${ }^{14}$ however, have consistently construed this injunctive power narrowly. It has been interpreted to represent the power to seek temporary emergency relief only where normal enforcement procedures are too slow or cumbersome to alleviate an immediate threat to workers. ${ }^{15}$

judge, and can be appealed to the entire Commission. Decisions of the OSHRC, like uncontested orders by OSHA, represent "final" administrative orders. 29 U.S.G. § 661 (1976 \& Supp. 1980). Decisions of the OSHRC can be appealed, by either the employer or OSHA, to the federal courts of appeals. 29 U.S.C. $\S 660$ (1976). Prosecutions for criminal violations are handled conventionally, being referred by OSHA to the Department of Justice for prosecution in the federal district courts.

5. See 29 U.S.C. $\S 666(a)$-(e) (1976). The various special citation provisions at 29 U.S.C. § $666(f)-(h)(1976)$ are not addressed in this Note. These provisions prohibit such acts as giving advance notice of inspections, fling false records, and making false statements to OSHA inspectors, but no actions have ever been brought under most of these subsections. See Rothstein, OSHA After Ten Years: A Review and Some Proposed Reforms, 34 VAND. L. REv. 71, 109 (1981).

6. 29 U.S.C. $\$ 666(j)(1976)$.

7. 29 U.S.C. $\$ 666(\mathrm{a})(1976)$.

8. 29 U.S.C. $\S 666(e)(1976)$.

9. Id. The available criminal penalties are doubled when an employer has previously been convicted, but no employer has ever been prosecuted more than once under the OSHAct.

10. 29 U.S.C. \& 658(a) (1976).

11. 29 U.S.C. $§ 666$ (d) (1976).

12. OSHA Field OPERATIONS MANUAL, ch. XI(C)(7)(e), reprinted in O.S.H. Rep. (BNA), Ref.

File 77:3704.

13. 29 U.S.C. § 662 (1976).

14. See supra note 4.

15. See infra p. 1461 \& notes $75-77$. 


\section{Griminal Sanctions}

The most spectacular failure of the OSHAct is that of the criminal sanction. Congress apparently intended that the criminal sanction represent the big gun in OSHA's enforcement arsenal: a particularly potent sanction reserved for the most egregious violations of the Act. ${ }^{16}$ Throughout their history, however, criminal penalties under the OSHAct have been virtually inoperative. After reviewing the history, this Note examines the potential of the criminal law, and concludes that the criminal law is an inappropriate regulatory tool in the context of workplace safety and health.

\section{A. The Criminal Portion of the Act is Moribund}

The use of the criminal sanction under the OSHAct has been all but non-existent. Only twelve cases have been criminally prosecuted under the Act since its inception. ${ }^{17}$ They are distinguished by a marked lack of suc-

16. See, for example, the remarks of Senator Yarborough in foor debate on the alternative bills: What about criminal penalties? The Williams-Yarborough bill provides for a penalty of $\$ 10,000$ and up to 6 months in jail for any willful violations of the standards. The Nixon administration bill makes no such provisions. . . . We say penalize the man who willfully violates the law. . . . A law without teeth is like a dull knife-it looks fine until you try to use it for its intended purpose.

116 CONG. REC. 37,625-26 (1970).

While the legislative history on the purposes of the criminal penalty is sparse, strong inferences can be drawn from its function and position in the Act. The invocation of criminal sanctions for a particular class of violations certainly connotes a heightened level of opprobrium, see, e.g., infra note 33, as does a definition singling out "willful violations . . . that cause death to any employee." 29 U.S.C. § 666(e) (1976).

The legislative history of the OSHAct reveals that Congress considered, over a period of several years, a variety of approaches to sanctions and remedies, which ranged from the entirely civil to the entirely criminal. The bill that originally passed in the Senate invoked criminal penalties for all willful violations of OSHA standards. S. 2193, 91st Cong., 1st Sess. § 14(c) (1970). The House bill contained an entirely civil enforcement scheme. H.R. 19,200, 91st Cong., 2d Sess. \$17(a)-(d) (1970). For a detailed examination of the many alternative bills considered by Congress, see Levin, OSHA and the Sixth Amendment: When is a "Civil" Penalty Criminal in Effect? 5 HastINGs CONST. L.Q. 1013, 1014-20 (1978); Sheahan, The Employer's Criminal Liability Under OSHA, 15 CRIM. L. BULL. 322, 323-26 (1979). See also Sullivan, Independent Adjudication and Occupational Safety and Health Policy: A Test for Administrative Court Theory, 31 AD. L. REV. 177, 181-83 (1978) (discussing administrative structure of OSHRC and OSHA). The original Senate bill had the support of organized labor, see Levin, supra, at 1017; while the House bill was favored by industry, see Sullivan, supra, at 182.

17. United States v. Newton Roofing and Sheet Metal Co., Cr. No. 4-82-28 (N.D. Tex. June 25, 1982) (corporation fined $\$ 8000$ after pleading guilty to willful violation involving fatal fall from unguarded skylight opening); United States v. Hughey Constr. Corp., Cr. No. 81-16D (W.D. Okla. Feb. 27, 1982) (corporation fined $\$ 7500$ on each of two counts after corporation and two officers pleaded gulty to willful violation resulting in fatal trench cave-in); United States v. Youngstown Sheet and Tube, Cr. No. H CR 82-14 (N.D. Ind. Feb. 18, 1982) (corporation fined $\$ 5000$ after pleading guilty to fatal willful violation involving motor vehicle); United States v. Jones, Cr. No. G-80-11 (S.D. Tex. Nov. 13, 1981) (corporation Farmers Export Co. not charged; hung jury resulted in acquittal of both defendant individuals on thirty-six count indictment based on death of eighteen workers in grain-elevator explosion); United States v. Port Allen Marine Services, Gr. No. 81-71A (M.D. La. Oct. 26,1981 ) (corporation fined $\$ 10,000$ after pleading guilty to willful violation resulting in 
cess on the part of the prosecution, and by the imposition of minimal sentences in the few cases in which guilty verdicts were obtained.

Incarceration is the threat that most markedly separates criminal penalties available under the OSHAct from civil ones. ${ }^{18}$ No one, however, has ever been incarcerated for violations of the Act. In only two cases have corporate officers been convicted as individuals, and those convictions followed pleas of guilty or nolo contendere. ${ }^{19}$ In both cases, the convicted officers were sentenced to probation. ${ }^{20}$ In the ten remaining cases, all cor-

drowning); United States v. Brown Steel Contractors, Cr. No. 80-G-254-S (N.D. Ala. Mar. 25, 1981) (corporation fined $\$ 5000$ after pleading nolo contendere to willful violation resulting in fatal fall); United States v. Nichols Contracting Corp., Cr. No. 80-169A (N.D. Ga. Aug. 11, 1980) (corporation fined $\$ 5000$ after pleading nolo contendere to willful violation resulting in fatal trench cave-in); United States v. S.O. Jennings Constr., Cr. No. 80-00098-A (E.D. Va. July 31, 1980) (corporation granted motion for acquittal; fatal trench cave-in); United States v. Pinkston-Hollar, Inc., 4 O.S.H. Cas. (BNA) 1697 (D. Kan. 1976) (corporation and officers acquitted after trial; fatal fall); United States v. Crosby \& Overton, No. CR-74-1832-F (C.D. Cal. Jan. 14, 1975) (corporation and two officers pleaded nolo contendere to willful violation involving lethal fumes in closed tanks); United States v. Dye Constr. Co., No. 73-CR-417 (D. Colo. Feb. 6, 1974), aff'd, 510 F.2d 78 (10th Cir. 1975) (all counts against president dismissed; corporation convicted and fined $\$ 3500$ for willful violation resulting in fatal fall); United States v. Turoon Co., Cr. No. 72-0-239 (D. Neb. Jan. 24, 1974) (president acquitted by jury; corporation fined $\$ 5000$ for willful violation).

The cases so singled out have had particularly compelling fact situations. For a detailed discussion of the four earliest cases, see Levin, Crimes Against Employees: Substantive Criminal Sanctions Under the Occupational Safety and Health Act, 14 AM. CRIM. L. REV. 717, 735-36 (1977). See also infra note 20 (discussing United States v. Crosby \& Overton).

18. It could also be argued that the "stigma" of criminal conviction separates OSHAct criminal penalties from civil ones. But the near absence of convictions of individual corporate officers undermines the significance of such a stigmatic deterrent. See infra P. 1453 \& note 39 (arguing that "stigma" plays no distinctive or important role when applied to corporations).

19. United States v. Hughey Constr. Co., Cr. No. 81-16D (W.D. Okla. Feb. 27, 1982); United States v. Crosby \& Overton, No. CR-74-1832-F (C.D. Cal. Jan. 14, 1975). See supra note 17. While the courts have generally accepted OSHA's position that corporate officers are liable as individuals for charges relating to OSHAct violations, the issue remains somewhat clouded. Further confusion persists, amidst very little case law, as to whether such liability arises directly under the OSHAct, or under 18 U.S.C. $\S 2$ (1976) for "aiding and abetting" the corporate violator. The confusion arises from the fact that 29 U.S.C. $\$ 666($ c) (1976) limits liability to "any employer," but makes available the sanction of incarceration. The conclusion that corporate officers are not individually liable would presumably limit the use of incarceration to individuals managing unincorporated partnerships or proprietorships, a seemingly bizarre result.

While the court in Crosby \& Overton held corporate officers individually liable, it is not clear whether officers in that case were convicted under 29 U.S.C. $\$ 666(e)$ (1976) or 18 U.S.G. \& 2 (1976). In United States v. Turcon Co., Cr. No. 72-0-239 (D. Neb. 1974), the court held that the corporate president could be charged as an aider and abettor, but not as a violative employer. See Sheahan, supra note 16, at 329-33. The only written opinion addressing the question is United States v. Pinkston-Hollar, Inc., 4 O.S.H. Cas. (BNA) 1697 (D. Kan. 1976). The court rejected the corporate vice president's claim that he could not be prosecuted under either 29 U.S.C. $\$ 666($ e) (1976) or 18 U.S.C. $\S 2$ (1976), and held that the officer's status as an "employer" was a question of fact to be submitted to the jury. 4 O.S.H. Cas. (BNA) at 1699.

20. In United States v. Crosby \& Overton, No. CR-74-1832-F (C.D. Cal. Jan. 14, 1975), the corporation and two officers were charged with willfully failing to provide required safety equipment to employees working in chemical tanks containing poisonous gas residues. See Levin, supra note 17, at 736. The officers admitted to having been aware that the exhaust equipment was faulty, and to having known that other companies in the industry had suffered fatalities under similar circumstances. The defendants had attempted to conceal evidence of the violation, and had committed the same violation again after being arraigned. According to Levin, while the Justice Department re- 
porate officers were either not charged or were acquitted. The corporate defendants were convicted in seven of those cases, five of them after entering pleas of guilty or nolo contendere. ${ }^{21}$ The five cases which have actually gone to trial have produced one hung jury, two complete acquittals, and two fines of $\$ 5000$ and $\$ 3500$ respectively. ${ }^{22}$ This paucity of convictions and of stiff penalties is not explained by a lack of criminally punishable violations. Numerous cases of willful violations resulting in death are cited by OSHA inspectors. Many such cases, however, are sanctioned civilly. ${ }^{23}$

\section{B. The Limitations of the Criminal Law}

The failure of the criminal sanction under the OSHAct is unsurprising. Historically, criminal convictions of corporations are slow, costly, and difficult to obtain; and of highly questionable usefulness even when achieved. The failures of the criminal sanction under the OSHAct result not from particular statutory flaws that could be remedied with some minor adjustments, but from the fundamental inappropriateness of the criminal law as a regulatory device in the occupational safety and health context.

\section{Convictions are Difficult to Achieve}

One key set of impediments to the successful prosecution of criminal cases against corporations is the various procedural strictures associated with the criminal law. Most notably these include the heavier burden of proof. Stricter construction of the statute in the criminal context is also a possibility, although the case law remains ambiguous. ${ }^{24}$ While some legis-

quested strong exemplary sentences including jail terms, the court limited its sentence to four years of probation for both the corporation and the convicted officers. Id.

21. See supra note 17.

22. See supra note 17.

23. See, e.g., Georgia Electric Co. v. OSHRC, 595 F.2d 309 (5th Cir. 1979) (following electrocution of worker, employer cited for willful violation of regulations regarding erection of light poles near power lines); Cedar Constr. Co. v. OSHRC, 587 F.2d 1303 (D.C. Cir. 1978) (employer fined $\$ 4750$ for willful violation following fatal trench cave-in; employer had been cited repeatedly for similar violations); Secretary v. East Texas Steel Fabricators, 9 O.S.H. Cas. (BNA) 1750 (OSHRC 1981) (employer fined $\$ 3500$ for willful violation following electrocution of employee working with crane near power lines); Secretary v. J. Roy Wise, Inc., 8 O.S.H. Cas. (BNA) 1691 (OSHRC 1980) (employer fined $\$ 5600$ for willful violation following fatal trench cave-in; employer warned repeatedly on day of accident that trench was inadequately sloped and dangerous). See also infra note 42.

24. Sheahan argues that the tension between the liberal construction to be accorded remedial legislation and the strict construction appropriate to a criminal statute has played a role in judicial interpretation of the OSHAct. He argues that the issue of whether a given employer "affects commerce," and is thus covered by the Act, has been more liberally construed in civil cases. Sheahan, supra note 16 , at $326-27$.

Levin rejects the argument that the term "willfulness" is to be construed more strictly in the criminal context of $\S 666(\mathrm{e})$ than in the civil context of $\S 666(\mathrm{a})$. See Levin, supra note 17, at 723-30. But see National Steel \& Shipbuilding Co. v. OSHRC, 607 F.2d 311, 314-15 (9th Cir. 1979); Intercounty Constr. Co. v. OSHRC, 522 F.2d 777, 780 (4th Cir. 1975) ("willfulness is used in the mere cognitive sense in civil statutes, and connotes bad purpose only when an element of a criminal act"). 
lators recognized such problems at the time the OSHAct was passed, others argued that the criminal sanction was nevertheless a necessary element of a strong and effective enforcement mechanism. ${ }^{25}$ The subsequent history of enforcement under the Act, however, belies such a contention.

The contrast of forums between criminal and civil OSHAct proceedings adds to the elusiveness of convictions. Juries, even more than administrative law judges or the OSHRC, are generally reluctant to convict corporations and their officers of crimes. ${ }^{26} \mathrm{~A}$ criminal trial also presents simple mechanical problems for OSHA that are not present in civil cases. OSHA lawyers must convince a United States Attorney that there is a case worth bringing. ${ }^{27}$ The United States Attorney often must then obtain an indictment, and go through a full-fledged criminal trial. Budget-strapped and interested in cost-effectiveness, OSHA must discount the limited potential gains from this investment of time and expense by the considerable unlikelihood of a conviction. Almost invariably, the balance comes down against criminal prosecution.

\section{Criminal Convictions of Corporations are of Questionable Usefulness}

The aims of the criminal law, and of sanctions in general, have been characterized variously. ${ }^{28}$ For the purposes of discussion, those aims will

\section{Senator Dominick made his concerns explicit:}

[U]nder the provisions of the substitute, we have a civil not a criminal penalty for a willful or repeated violation. That has been treated with some care. We did it this way because ... most of us know how difficult it is to get an enforceable criminal penalty in these types of cases. Over and over again, the burden of proof under a criminal-type allegation is so strong that you simply cannot get there, so you might as well have a civil penalty instead of the criminal penalty and get the employer by the pocketbook if you cannot get him anywhere else. 116 CONG. REC. 37,338 (1970) (remarks in floor debate). Senator Yarborough, however, argued that the Act would be greatly weakened without criminal penalties, see supra note 16 . The House Labor Committec also exhibited ambivalence over this dilemma: "American industry cannot be made safe by enacting a Federal law which emphasizes punishment. Nevertheless, this measure recognizes that effective enforcement and sanctions are necessary for serious cases." H.R. REP. NO. 1291, 91st Cong., 2d Sess. 26 (1970) (report accompanying H.R. 16,785).

26. See, e.g., Comment, The Criminal Responsibility of Corporate Officials for Pollution of the Environment, 37 ALB. L. REV. 61, 65-66 (1972) [hereinafter cited as Comment, Criminal Responsibility]; Comment, Increasing Community Control Over Corporate Crime-A Problem in the Law of Sanctions, 71 YALE L.J. 280, 292 n. 50 (1961) [hereinafter cited as Comment, Community Control].

Some writers have pointed out that this is generally less of a problem where the defendant is a corporation, rather than a corporate officer. See infra note 52. The dismal history of prosecutions, however, as well as the uniformly small sanctions that have been meted out, indicate that jury ambivalence remains a problem.

27. Precise records of the number of cases referred by OSHA to the Justice Department have been kept only for the last two years. Of the twenty-four cases referred for prosecution in that period, the Justice Department has prosecuted seven. The screening function performed by the Justice Department operates in addition to a similar role played by OSHA's national office, which sends to Justice only about $60 \%$ of the cases referred from regional OSHA offices. Telephone interview with Harold Engel, Counsel for Regional Trial Litigation at OSHA (March 11, 1982).

28. Sec, e.g., W. Clark \& W. MARShald, A TREatise ON THE LaW OF CRIMEs 71-75 (7th ed. 1967); H. PACKER, THE LIMITS OF THE CRIMINAL SANGTION 35-61 (1968); Developments in the Law-Corporate Crime: Regulating Corporate Behavior through Criminal Sanctions, 92 HARV. L. 
be differentiated here into three broad categories: "punishment,"29 "general deterrence,", and "specific rehabilitation." punishment is uniquely situated. The consequentialist goals of general deterrence and specific rehabilitation are common to both civil and criminal enforcement. ${ }^{32}$ Punishment, on the other hand, is associated distinctively with the criminal law, and is often tied closely to the issue of moral culpability. ${ }^{33}$ While some civil sanctions can unquestionably be every bit as burdensome as criminal sanctions, attempts by the Supreme Court to discern whether a given penalty is effectively a criminal sanction have repeatedly focused upon the presence or absence of an intent to punish moral culpability. ${ }^{34}$

REV. 1227, 1231-33 (1979) [hereinafter cited as Developments in the Law]. Clark and Marshall break the consequentialist goals of sanctioning into a much longer list than the one articulated here, distinguishing such aims as prevention, education, retaliation, and the expression of indignation. Such subtlety, however, is unnecessary for present purposes.

29. "Punishment," in the sense intended here, has been referred to by some authors as "retribution." See, e.g., H. PACKER, supra note 28, at 37-39. "Punishment" is used here to refer to the imposition of penalties on the moral ground that the employer deserves to be sanctioned, as contrasted with justifications based on the behavior-modifying consequences of sanctioning.

30. "General deterrence" is used here to refer to the behavioral effect on all employers of making specific activities less profitable, or generally less attractive.

31. "Specific rehabilitation" as used here may represent either voluntary or coerced reform; it is meant to refer to any attempt to shape prospectively the behavior of the specific defendant at bar. It may also include the aim of incapacitation, which is represented in its classic form by incarceration, but which can be effected upon a corporation through an injunction, administrative order, or even dissolution.

32. In the context of corporate regulation, the power of the government to impose specific rehabilitation in the absence of criminal conviction is sweeping. For example, when the Securities and Exchange Commission (SEC) determines' that "any person has violated, is violating, or is about to violate" the securities laws, the SEC is empowered to "publish information concerning such violations." 15 U.S.C. $\$ 78 \mathrm{u}$ (1976). The SEC is also given the authority to petition the federal district courts for "writs of mandamus, injunctions, and orders" commanding immediate and future compliance with the Securities Exchange Act of 1934. Id. The National Labor Relations Board (NLRB) is empowered to issue broad cease-and-desist orders prohibiting unfair labor practices, and to require a violator to "make reports from time to time showing the extent to which it has complied with the order." 29 U.S.C. $\S 160$ (c) (1976). Where a union is determined to have a "proclivity for harmful conduct," the cease-and-desist order may bar "not only continued illegal conduct directed at the employer in the case at bar, but also against any other employer in the union's jurisdiction." R. GORMAN, BASIC TEXT ON LABOR LAW UNIONIZATION AND COLLEGTIVE BARGAINING 287 (1976). The Food and Drug Administration is authorized to seize summarily goods suspected of being "adulterated or mislabelled." 21 U.S.C. $\$ 334$ (1976). Sellers of food and drugs are particularly sensitive to the negative publicity which attends such a seizure.

33. See, e.g., Hart, The Aims of the Criminal Law, 23 LAW \& CONTEMP. ProBS. 401, 404-05 (1958) ("What distinguishes a criminal conviction from a civil sanction and all that distinguishes it, it is ventured, is the judgment of community condemnation which accompanies and justifies its imposition."); Kadish, Some Observations on the Use of Criminal Sanctions in Enforcing Economic Regulations, 30 U. CHI. L. REV. 423, 440-44 (1963) (arguing that moral culpability is necessary to justify "stigma of moral blame" associated uniquely with criminal sanctions).

34. See Kennedy v. Mendoza-Martinez, 372 U.S. 144 (1963) (sanction of expatriation against draft evader held to be "evidently punitive," and to entitle defendant to Sixth Amendment protections). The criteria articulated by the Court in delineating congressional lattitude to prescribe civil rather than criminal penalties include: "Whether the sanction . . . has historically been regarded as punishment, whether it comes into play only on a finding of scienter, [and] whether its operation will promote the traditional aims of punishment-retribution and deterrence." 372 U.S. at 168. See Trop 
Portions of the legislative history, as well as the structure of the OSHAct itself, indicate that punishment was a key legislative motive behind the retention of a criminal sanction. ${ }^{35}$ As numerous authors have noted, however, the aim of punishment in the context of corporate regulation is problematic. "Punishment" in any conceptually meaningful sense cannot accurately be said to be applied to corporations. ${ }^{37}$ However much moral condemnation society may wish to express, virtually the only punitive sanction that can be imposed on a corporation is the direct or indirect limitation of profits. ${ }^{38}$ Incarceration is obviously unavailable. Any "stigma" associated with criminal penalties against a corporation is useful, if at all, only as a roundabout means of affecting profits. ${ }^{39}$

v. Dulles, 356 U.S. 86 (1958) (civil sanction of expatriation for desertion from military during wartime held to be explicable only as punishment, and hence impermissible).

The Fifth Circuit Court of Appeals applied these cases in holding that the sanctions under the OSHAct are not sufficiently "punitive" to entitle the employer to Sixth Amendment protections. Atlas Roofing Co. v. OSHRC, 518 F.2d 990, 1000-11 (5th Cir. 1975), aff'd on other grounds, 430 U.S. 442 (1977) (holding only that defendant had no Seventh Amendment right to jury trial).

For a general discussion of the criminal/civil distinction as it relates to the OSHAct, see Levin, supra note 16.

35. The issue of punishment is a repeated theme throughout the Act's legislative history, although references to it are often accompanied by the disclaimer that it cannot represent the only goal of the OSHAct. See H.R. REP. No. 1291, supra note 25, at 26; see also supra note 16. On possible inferences of a punitive motive behind criminal penalties, see Levin, supra note 16, at 1017-20.

36. See, e.g., Developments in the Law, supra note 28, at 1301-02; Comment, Criminal Responsibility, supra note 26, at 62-64; Comment, Is Corporate Criminal Liability Really Necessary? 29 Sw. L.J. 908, 917-26 (1975) [hereinafter cited as Comment, Corporate Liability]; Comment, Community Control, supra note 26 , at $283-90$.

37. In Developments in the Law, supra note 28 , at 1237 , the authors contend that "the argument that retribution cannot be involved [in the imposition of criminal sanctions against corporations] is unconvincing." This contention is based largely on the conclusion that violations of regulatory laws under some circumstances are not morally neutral. The existence of some moral culpability, however, does not require that the culpability be punished, nor that it serve as a basis for the imposition of sanctions. A predictable counter-argument is that this is mere subterfuge, that whatever the claimed intention behind sanctions, at least some violations of worker welfare are so outrageous as to make an impulse to retribution, or even to vengeance, inevitable. Even granting this proposal, arguendo, it is idle to engage in what must ultimately be a futile attempt to inflict "punishment" on an inanimate corporation.

38. A rich range of sanctions has admittedly been applied against corporations at one time or another. Corporations have been fined directly. They have been injunctively prohibited from certain markets or operating practices. They have had their products seized, and been forced to recall their products at immense cost. They have been required to engage in public advertising campaigns admitting that they have misled the public. See Warner-Lambert Co. v. FTC, 562 F.2d 749 (D.C. Cir. 1977) (defendant required to correct prior advertising that its product, Listerine mouthwash, prevented colds and sore throats). Indeed, they have even been placed on criminal probation pursuant to the OSHAct. See United States v. Crosby \& Overton, No. GR-74-1832-F (C.D. Cal. Jan. 14, 1975) (discussed supra pp. 1449-50 \& notes 19-20). In terms of "punishment," however, none of these sanctions has been significant except insofar as it has affected corporate profits. See also infra note 39.

39. This stigma is not comparable to the stigma that criminal conviction visits upon an individual. An individual has a wide range of needs and desires that are affected by the criminal stigma. Not only his ability to earn a livelihood, but also his self-esteem, freedom of movement, and relationships with peers and the community at large may all be affected. This is not the situation faced by a "stigmatized" corporation. The corporation may lose sales, or the trust of its employees, but ultimately the corporation has no complex array of psychological and physical wants and needs analogous to those of the individual. See, e.g., H. PACKER, supra note 28, at 360-62; Kadish, supra note 33, at 434-35; 
The failure of the criminal law to make a unique punitive contribution to the sanctioning of OSHAct violators could be overlooked if criminal enforcement made a significant addition to OSHA's deterrent capabilities. No such addition, however, is attributable to the criminal sanction. The criminal penalties currently available are extremely modest in comparison to the expense of the actions they are supposed to encourage. ${ }^{40}$ They are also radically discounted by the overwhelming unlikelihood of conviction. Employers know that, unless they actually kill or maim a worker, their chances of even being inspected by OSHA are quite remote. ${ }^{41}$ When a death does occur, the employer's chance of being criminally prosecuted and convicted remain extremely small..$^{42}$ When thus discounted, only an extraordinarily costly or unpleasant sanction can create a meaningful deterrent. Judges and juries in OSHAct trials, however, are disposed to mete out penalties even smaller than those statutorily available, ${ }^{43}$ a tendency confirmed in other regulatory contexts. ${ }^{44}$ The combination of that pattern with the strictures on levels of inspection, prosecution, and conviction, serve to insure that no meaningfully deterrent sanction can be reliably provided by the criminal law.

\section{Criminal Liability for Individuals}

Although corporate officers have been convicted as individuals under the OSHAct only twice, ${ }^{45}$ individual criminal liability for corporate officers is

Comment, Community Control, supra note 26, at 287-88.

40. See infra note 59 .

41. For a discussion of the woeful inadequacy of OSHA's inspectorate, see Blumrosen, Ackerman, Kligerman, VanSchaick, \& Sheehy, Injunctions Against Occupational Hazards: The Right to Work Under Safe Conditions, 64 CALIF. L. REV. 702, 715-16 (1976); Rothstein, supra note 5, at 94-95. OSHA figures compiled by Rothstein indicate that the inspectorate would have to be more than quadrupled (from 1979 levels) to achieve what Eula Bingham, Assistant Secretary of Labor for OSHA in the Carter Administration, estimates as a minimal level of inspection. That level is one inspection per year of employers in high-risk industries, and one inspection per decade of employers in low-risk industries. Even if inspections of low-risk industries under this scheme were abandoned entirely, OSHA would need to more than triple its number of inspectors. Rothstein, supra note 5, at 94-95.

42. Figures are not available indicating how many deaths occur as a result of OSHAct violations each year. Presumably, however, the worst cases are concentrated among the handful of cases referred from OSHA Regional Offices to Washington for prosecution. Even among that highly skewed sample, however, only a small percentage of the cases have resulted in conviction in the years that records have been accurately kept. Of the forty-two cases referred from the Regional Offices since November 1979 , twenty-four were in turn referred to the Justice Deptartment for prosecution. Only six of those twenty-four cases have resulted in convictions, see supra notes 17, 21; telephone interviews with Harold Engel, Counsel for Regional Trial Litigation at OSHA (March 11, 1982), and Julian S. Greenspun, Deputy Chief of Litigation, General Litigation and Legal Advice Section, Criminal Division, Department of Justice (June 28, 1982).

43. See supra pp. 1449-50 \& notes 19-23.

44. See, e.g., Coffee, Corporate Crime and Punishment: A Non-Chicago View of the Economics of Criminal Sanctions, 17 AM. CRIM. L. REV. 419, 456-57 (1980); Comment, Criminal Responsibility, supra note 26, at 64-66 (environmental pollution).

45. United States v. Hughey Constr. Co., Gr. No. 81-16D (W.D. Okla. Feb. 27, 1982); United States v. Grosby \& Overton, No. CR-74-1832-F (C.D. Cal. Jan. 14, 1975). See supra pp. 1449-50 \& 
a common legislative choice. ${ }^{46}$ It is also a favorite recommendation of many writers attempting to circumvent the problems associated with corporate criminal liability. ${ }^{47}$ The attractions of such liability generally include the hope of more genuine punishment, more effective deterrence, and the opportunity to focus the sanction directly upon the culpable party. An opposing body of literature, however, explores the myriad problems associated with criminal liability for corporate officers ${ }^{48}$ Those problems generally relate to the difficulty of conviction and to concerns of fairness. ${ }^{49}$ In the context of OSHAct violations, the arguments of this latter group of critics are more persuasive. ${ }^{50}$

Judges and juries are often reluctant to convict and incarcerate corporate officers. ${ }^{51}$ Cases are common, both generally and under the OSHAct specifically, in which corporations are criminally convicted while corporate offiers are acquitted..$^{52}$ OSHAct criminal prosecutions have most of

notes 19-20.

46. See generally Stone, The Place of Enterprise Liability in the Control of Corporate Conduct, 90 YALE L.J. 1, 28-35 (1980) (discussing variety of theories of "agent liability" in a range of statutory contexts, including antitrust, environmental pollution, bribery, and unfair labor practices).

47. See, e.g., Coffee, supra note 44, at 458-62; Mueller, Mens Rea and the Corporation, 19 U. PITT. L. REv. 21, 44-45 (1957); Developments in the Law, supra note 28, at 1373-74; Comment, Corporate Liability, supra note 36, at 925-26. See also Whiting, Criminal Antitrust Liability of Corporate Representatives, $51 \mathrm{KY}$. L.J. 434, 447 (1963) (addressing stigma attending mere indictment of corporate officers, as well as assaults on dignity wrought by rituals accompanying arrest and prosecution); Comment, Community Control, supra note 26, at 298 (advocating "an affirmative duty on corporate executives to exercise reasonable care in preventing acquisitive crime within the area of corporate business under their control"); id. at 297-98, 301-05.

48. The problems of increased difficulty of conviction, ambiguous responsibility, and the possibility of the fined corporate officer being reimbursed by his employer are addressed repeatedly in the literature. See, e.g., K. ElzINGA \& W. BREIT, THE ANTITRUST PENALTIES: A STUDY IN LAW AND ECONOMICS 43, 132-33 (1976); Stone, supra note 46, at 28-35; Comment, Criminal Responsibility, supra note 26 , at 64-75.

49. These problems are not entirely separate, as fairness concerns often play a key role in jury reluctance to convict.

50. Coffee, an advocate of individual criminal liability, concedes that statutes like the OSHAct present a special case:

[I]n the case of health and safety statutes which impose vicarious criminal liability on corporate officers ... the odds are high that any campaign to invoke these laws will be substantially offset by judicial nullification when sentencing judges confront 'flesh and blood' defendants having impeccable backgrounds, community ties, and tearful families.

Coffec, supra note 44, at 462 (citing to OSHAct).

51. See, e.g., K. EliziNGA \& W. BREIT, supra note 48, at 43; Coffee, supra note 44, at 456-57; Comment, Corporate Liability, supra note 36, at 922-24.

52. Seven of the nine OSHAct cases resulting in guilty verdicts fit this description. See supra pp. 1448-50 \& notes 17-21. See also United States v. American Stevedores, 310 F.2d 47, 48-49 (2d Cir. 1962) ("[E]ven if the verdicts [of conviction for the corporation and acquittal for the corporate officer] were inconsistent, it is well settled that consistency in these verdicts is not required."), cert. denied, 371 U.S. 969 (1963); United States v. General Motors Corp., 121 F.2d 376, 411 (7th Cir. 1941) ("We cannot understand how the jury could have acquitted all of the individual defendants. As a matter of logic, reconciliation between the verdict of guilt and verdict of acquittal is impossible."). But cf. Pevely Dairy Co. v. United States, 178 F.2d 363, 370-71 (8th Cir. 1949) (presumption of correctness of jury's verdict is undermined by conviction of corporate defendant and acquittal of all individual defendants). See generally Developments in the Law, supra note 28, at 1367-68 n.14; cf. Gribetz \& Grad, Housing Code Enforcement Reviewed, 23 J. HousING 511, 513 (1966). 
the more telling characteristics that commentators have identified in attempting to explain this phenomenon. Like most regulatory crimes, OSHAct violations are usually committed by sympathetic defendants in the course of their employment. ${ }^{53}$ The relatively remote relationships between the OSHAct violator and his victim, and between the violative act and the consequent injury or death, also presumably diminish the perceived moral blameworthiness of the violation. A related phenomenon is the problem of diffuse responsibility, and the fuzzy line between corporate policy and individual action. ${ }^{54}$ Attempting to fix criminal liability on the low-level supervisory personnel who are often most directly responsible for OSHAct violations carries overtones of scapegoating. ${ }^{55}$ Some authors have suggested that the best way to avoid problems in affixing responsibility is to hold higher corporate officers to a duty of diligent supervision, ${ }^{56}$ or even to impose vicarious liability upon the highest corporate officer for the actions of his subordinates. ${ }^{57}$ This approach undeniably serves to focus

53. See Kadish, supra note 33, at 435-37 (regulatory crimes are committed by "respectable people in the pursuit of profit," and thus fail to inspire "sustained public moral resentment"). Ball and Friedman discuss the potential for jurors to sympathize more readily with a defendant who has committed a regulatory crime which, while admittedly illegal, is one the juror can imagine committing himself in a bad moment. Ball \& Friedman, The Use of Criminal Sanctions in the Enforcement of Economic Legislation: A Sociological View, 17 STAN. L. REV. 197, 217-19 (1965). Ball and Friedman contrast such acts with more traditional common crimes, which they argue appear to jurors as alien. Sutherland, among others, viewed similar tendencies as naked favoritism, arguing that courts and jurors generally accord businessmen lenient treatment as a result of their class standing. E. SUTHERIAND, WHITE COLLAR CRIME 46-49 (1949).

54. See Kadish, supra note 33, at 430-35 (discussing "problem of corporate criminality"); Note, Structural Crime and Institutional Rehabilitation: A New Approach to Corporate Sentencing, 89 YALE L.J. 353, 357-60 (1979) (attributing to "organizational complexity and obscured individual liability ... . what might be called 'structural crimes" ").

55. Dissatisfaction with the sanctioning of "direct actors" has been expressed often. Sce, e.g., 1 UNITEd STATES NATIONAL COMMISSION ON REFORM OF FEDERAL CRIMINAL LAWS, WORKING PAPERS 200-01 (1970) (acknowledging "general belief that many individual employees who violate . . . regulatory statutes do so because they are under pressure, although not necessarily stated pressure, from higher levels to increase profits in any way possible"); Developments in the Law, supra note 28, at 1261 (citing both fairness and deterrence problems).

Arguments of scapegoating are particularly compelling under the OSHAct, where the individual most directly responsible for the violation, and sometimes the only party who could be argued to have acted "willfully," is often a site foreman or shopsteward. Criminal penalties directed at such lowly employees are not only elusive, but also hardly seem calculated to affect corporate behavior.

56. See, e.g., S. 1630, 97th Cong., 2d Sess. § 403 (1982) (bill to reform United States Criminal Code; "a person is criminally liable for an offense based upon conduct that he engages in or causes .. . on behalf of an organization to the same extent as if he engaged in or caused the conduct . . . on his own behalf'); Criminal Code Reform Bill, S. 1437, 95th Cong., 2d Sess. § 403(c) (1978) (incorporating standard of reckless supervision); Developments in the Law, supra note 28, at 1270-75 (surveying arguments and proposals for standards of "reckless supervision" and "negligent supervision"); Comment, Community Control, supra note 26, at 297-98, 302-05 (proposing imposition of "affirmative duty on corporate executives to exercise reasonable care in preventing acquisitive crime within the area of corporate business under their control").

57. Despite potential fairness problems, such vicarious liability has sometimes been imposed in other regulatory contexts, and has been upheld by the Supreme Court. See, e.g., United States v. Dotterweich, 320 U.S. 277 (1943) (absolute vicarious liability imposed upon corporate president for shipping adulterated and misbranded drugs); Carolene Prods. Co. v. United States, 323 U.S. 18 
liability for compliance upon a specific person. Having strayed so far from the punishment of moral culpability, however, such an approach raises questions of whether a legislature ought to pursue this purpose through the criminal law. A direct administrative order accomplishes the same focusing of responsibility, but does so prospectively and with ample notice to the responsible individual. Administrative orders also offer advantages in ease and predictability of enforcement, which strengthen the incentives to the identified corporate officer for assuring the compliance of his subordinates.

Individual criminal liability, then, presents difficulties that make criminal convictions even more elusive than when pursued against the employer corporation, and hence raises additional barriers to effective deterrence. While the imposition of vicarious liability may serve to focus responsibility on individuals, it leaves the central drawbacks of criminal enforcement untouched. In the absence of any distinctive contribution, the difficulties that attend the use of the criminal law render its continued use under the OSHAct difficult to justify.

\section{Civil Enforcement}

The deficiencies of the criminal law as a tool for enforcing OSHA standards need not undermine OSHA's entire enforcement panoply. Prudently crafted civil sanctions and remedies could provide workable alternative means of accomplishing the most important purposes of the criminal sanction. A credible threat of unusually severe civil sanctions for unusually serious violations could serve as a highly useful deterrent device. Similarly, sufficiently broad directive-order powers could enable OSHA to effect prospective rehabilitation. Unfortunately, OSHA's currrent civil powers offer no such promise. With civil powers too weak, narrow, and inflexible to compensate for the vacuum left by the deficiencies of criminal penalties, OSHA is left inadequately equipped to achieve its responsibilities.

\section{A. The Section 666 Civil Citation}

Civil fines are immensely useful, and it is not contended here that they should be eliminated from the OSHAct. For the vast run of lesser violations, the simple post-hoc civil fine represents the ideal quick and routine tool. Such fines do have limitations, however, and these should be recognized. Post-hoc civil fines lack the flexibility to serve as a useful prospective rehabilitative tool, and are limited in their deterrent capability. 
The most obvious method for strenghtening the deterrent effect of civil OSHAct fines is simply to make them larger. Critics of the Act have repeatedly called for increasing the size of fines available under the Act, and the need for such a change is not disputed here. ${ }^{58}$ Arguments that the Congress had no desire to impose upon industry the costs associated with greater deterrence are not persuasive. The costs of compliance with OSHA standards can be immense, sometimes running into the tens and even hundreds of millions of dollars. ${ }^{59}$ The Supreme Court has nevertheless rejected employers' arguments that OSHA is required to engage in cost-benefit analysis before promulgating standards. ${ }^{60}$ The Court has ob-

58. See, e.g., R. SMITH, THE OCCUPATIONAL SAFETY AND HEALTH ACT: ITS GOALS AND ITS ACHIEVEMENTS 63 (1976) (citing statistics on average fines actually imposed); Viscusi, The Impact of Occupational Safety and Health Regulation, 10 BELL J. ECON. 117, 133-37 (1979) (statistical and economic analysis of OSHAct fines, concluding that they are too small to spur significant health and safety investment); Rothstein, supra note 5, at 108-10 (criticizing low enforcement and high settlement rates, in addition to diminutive fines).

59. While self-interest undoubtedly serves to exaggerate industry claims as to the cost of compliance with various standards, they are offered here as an approximate scale. OSHA estimated the cost to the textile industry of compliance with its cotton dust standard at $\$ 656.5$ million, see American Textile Mfrs. Inst. v. Donovan, 452 U.S. 490, 525 n. 44 (1981), an estimate challenged by industry petitioners as too low, id. at 523-26. In Secretary v. Continental Can Co., 4 O.S.H. Cas. (BNA) 1541, 1544 (OSHRC 1976), a manufacturer of metal cans claimed that compliance with OSHA's noise standard would require an initial investment by the defendant of $\$ 33,230,000$, and an additional $\$ 175,000$ in yearly maintenance.

An interesting alternative perspective on these compliance costs is provided in M. BAILEY, REDUC. ING RISKS TO LIFE 20-27 (1979). Bailey examines the "cost per human life saved" of compliance with several regulatory standards, figures that are admittedly subject to considerable exaggeration by industry. He reports testimony by a representative of the Council on Wage and Price Stability to OSHA in 1976 that this cost-per-life-saved figure under OSHA's coke oven emission standard varied from \$4.5 million to $\$ 158$ million. Similar testimony to OSHA by an industry representative in 1978 offered the rather inexact calculation that the analogous figure for compliance with OSHA's acrylonitrile exposure standard varied between $\$ 1,963,000$ and $\$ 624,976,000$.

60. American Textile Mfrs. Inst. v. Donovan, 452 U.S. 490 (1981). The debate over OSHA's mandate centers on section $655(\mathrm{~b})(5)$ of the OSHAct, which states:

The Secretary, in promulgating standards dealing with toxic materials or harmful physical agents under this subsection, shall set the standard which most adequately assures, to the extent feasible, on the basis of the best available evidence, that no employee will suffer material impairment of health or functional capacity even if such employee has regular exposure to the hazard dealt with by such standard for the period of his working life.

29 U.S.C. $§ 655$ (b)(5) (1976) (emphasis added). OSHA has stringently construed this feasibility limitation. Defining "economic feasibility," OSHA has declared:

The employer's economic cost of correction is generally not considered to be a factor in the issuance of a citation.

... However, if the cost of implementing effective engineering, administrative or work practice controls, or combination, would so seriously jeopardize the employer's financial condition so as to result in the probable shutdown of the establishment or a substantial part of it, an extended correction date may be set.

OSHA INDUSTRIAL HYGIENE MANUAL ch. I (I)(4)(b), reprinted in O.S.H. Rep. (BNA) Ref. File 77:8007. In American Textile Mfrs., the Supreme Court explicitly upheld OSHA's claim that OSHA was not required to weigh costs against benefits in promulgating standards. 452 U.S. at 506-22.

For a detailed examination of the lower court case law on "feasibility," see Berger \& Riskin,

Economic and Technological Feasibility in Regulating Toxic Substances Under the Occupational Safety and Health Act, 7 Ecol. L.Q. 285, 324-26 (1978). Discussing the distinction between "technological" and "economic" feasibility, Berger and Riskin conclude:

[I]n enforcing feasible requirements, the Secretary may require an employer to go beyond the 
served that, "Congress understood that the Act would create substantial costs for employers, yet intended to impose such costs when necessary to create a safe and healthful working environment." ${ }^{\text {" } 1}$ Fines of at most $\$ 10,000$ are hardly adequate, as deterrent or coercive devices, to effect so sweeping a mandate. ${ }^{62}$

Even if fines were dramatically increased, however, they are not suited to carry the entire burden of enforcement. Post-hoc fines, no matter how large, perform a predominantly deterrent, rather than coercive function. They serve to deter violations generally, but not to insure that any particular employer implements specific reforms. OSHA could theoretically be empowered to increase fines progressively against a recalcitrant employer until adequate compliance is finally achieved. Given the staggering costs associated with some health and safety measures, however, the size of such fines would have to be exceedingly large. ${ }^{63}$ The advisability of such an approach is further mitigated by the low levels of inspection and enforcement under the OSHAct, as well as the considerable delays associated with each round of citation and contest. The administrative order provides a markedly superior device for coercing the particularly non-compliant employer, or for assuring the adoption of particularly expensive safeguards. ${ }^{64}$

\section{B. Abatement Orders and Imminent-Danger Injunctive Powers}

In addition to the simple post-hoc citation, OSHA's civil arsenal includes the agency's "abatement order" power. OSHA is empowered to order employers to correct, or "abate," ongoing violations, ${ }^{65}$ and to enforce

state of the actual technology in his industry. Not only may compliance be expensive, but an employer may be forced out of business through promulgated regulations. Such an approach regards safety and health compliance as a cost of doing business, and implicitly rejects individual employer defenses that compliance is not required if compliance costs exceed the economic benefit gained through improved safety and health.

Id. at 325-26 (citations omitted). See also Sullivan, supra note 16, at 184-94 (focusing on deference of OSHRC to OSHA's definition of "feasible"); Note, Occupational Noise: $A$ Watershed Issue for OSHA, 32 U. MIAMI L. REV. 667, 669-73 (1978) (examining meaning of "feasible" when used within specific standard).

61. American Textile Mfrs. Inst. v. Donovan, 452 U.S. 490, 519-20 (1981).

62. One possible rebuttal is that OSHAct fines are not the only deterrent to violative behavior. But worker compensation claims, and consequently employer insurance premiums, radically underrepresent the true "cost" of workplace injuries. Employers generally pay only medical expenses and lost wages, rather than full tortious damages. See generally Miller, The Occupational Safety and Health Act of 1970 and the Law of Torts, 38 LAW \& CONTEMP. PROBS. 612, 628-30 (1974).

63. Massive civil fines in this context are also distinctly unattractive. Regardless of the absolutist language of the OSHAct, costs associated with occupational safety and health protection are a continual political concern. Huge civil fines would take money directly away from corporate violators hence increasing the cost of the OSHAct to industry while doing nothing to benefit workers directly.

64. See infra pp. 1469-70 \& notes 109-20.

65. 29 U.S.C. \& 658(a) (1976). 
such orders with fines ${ }^{66}$ and possible contempt proceedings. ${ }^{67}$ This abatement power broadens OSHA's authority beyond mere deterrence, by adding a device for pursuing the prospective rehabilitation of specific employers. As such, it is directed toward goals similar to those proposed in this Note. Under the Act as it is currently structured, however, those goals are realized only marginally.

Citations for "failure to abate" create virtually no deterrence. Until an employer has actually been inspected and cited for non-compliance with OSHA standards, an abatement citation is not a possibility. The employer that takes no action to abate a violation until after it is cited can be fined only for violating the OSHA standard, not for violating an abatement order, so the threat of an abatement order creates no incentive for self-enforced pre-inspection compliance. The abatement order itself is also unnecessarily limited in scope. While OSHA can establish a method and timetable for compliance, it does not have the power to impose individualized oversight or safety programs beyond those that are necessary for bare compliance. ${ }^{68}$ Thus, even where the employer has proven to be a recalcitrant or habitual violator, OSHA has virtually no power to pursue the kind of broad prospective rehabilitation advocated in this Note. ${ }^{69}$

Other limitations of the abatement power affect its range of application and its coercive effectiveness. OSHA can cite an employer for failure to comply with an abatement order only by proving that a condition as reinspected is identical to the condition upon first inspection and that the violation has been continuously uncorrected. ${ }^{70}$ Thus, even an employer that is cited, corrects a violation, and then later returns to a condition of non-

66. 29 U.S.C. $\$ 666(\mathrm{~d})(1976)$.

67. Under 29 U.S.C. 660 (b) (1976), OSHA may seek a decree from a federal court of appeals to enforce abatement orders. Violation of that decree constitutes contempt of court.

68. The precise contours of OSHA's abatement-order powers are not clear, nor have they been ambitiously litigated. In Marshall v. Sullenberger, No. 80-2232 (3rd Cir. June 9, 1981), OSHA attempted to have a decree enforcing an abatement order entered against the purchasers of a corporation that had been in repeated and unabated non-compliance for over two years. In attempting to reach the purchasers, OSHA argued that its powers should be construed to encompass the authority to take such affirmative action as is necessary to effectuate the policies of the OSHAct. Brief for Secretary of Labor, id., at 7-8. These arguments were based in part on Golden State Bottling Co. v. NLRB, 414 U.S. 168 (1973), in which the Supreme Court held that the NLRB does possess such powers. Without expressly addressing this issue, however, the Third Circuit denied OSHA's motion for enforcement against the purchasers.

OSHA met with greater success in Brennan v. Tomco Stud Co., No. 74-1947 (7th Cir. March 21, 1975). Without elaboration, the court in that case granted OSHA's motion for a cease-and-desist order prohibiting future violations by the employer "in any like or related manner." Such judicial activism on behalf of OSHA, however, may be unique. See Brief for Secretary of Labor, Marshall v. Sullenberger, supra, at 14-15 (citing Tomco Stud).

69. See infra p. 1470.

70. OSHA FIELD OPERATIONS MANUAL ch. VIII(B)(5)(c), reprinted in O.S.H. Rep. (BNA) Ref. File 77:3108. See also M. ROTHSTEIN, Occupational SAFETY AND HEALTH LAW $\S$ 306, at 312-13 (1978 \& Supp. 1982). 
compliance cannot be cited for failure to abate. ${ }^{71}$ This constricted definition excludes those violators engaged in the repeated violation of a single standard, as well as those engaged in repeated or habitual violation of a variety of standards. As a coercive device, the abatement power also suffers from the same problem as the standard civil citation: it is too small to effect incentives commensurate with the purposes of the Act. Abatement orders are backed up by the threat of an assessed penalty of no more than $\$ 1000$ per day for non-compliance. ${ }^{72}$ The coercive effect of these fines is further limited by lengthy time-lapses before abatement orders take effect, as well as by OSHA's policy of limiting fines for failure to comply with abatement orders to ten times the daily assessed penalty. ${ }^{73}$

OSHA retains in its arsenal one final civil enforcement tool: the power to seek temporary restraining orders or emergency injunctions where an "immediate" or "imminent" threat to workers "exists which could reasonably be expected to cause death or serious physical harm." ${ }^{\text {" Confusion }}$ surrounds several key aspects of that power. In general, however, it has been interpreted by the courts to be quite limited. It is clear that these section 662 powers can be used as an interlocutory device to insure relief "pending the outcome of an enforcement proceeding," have generally been reluctant to construe OSHA's power to encompass the authority to seek permanent injunctions. ${ }^{76}$ The language of section 662 has also been read to restrict OSHA's power to seek injunctions to those situations in which other enforcement tools appear too cumbersome to effect immediate relief. ${ }^{77}$ Finally, the various procedural safeguards that

71. See, e.g., Secretary v. Montgomery AMC Drilling, Ltd., 5 O.S.H. Cas. (BNA) 1629, 1630 (OSHRC 1977).

72. 29 U.S.C. $\$ 666$ (d) (1976).

73. See OSHA FIELD OPERATIONS MANUAL ch. XI(C)(7)(e), reprinted in O.S.H. Rep. (BNA) Ref. File 77:3704. This ten-day limitation is apparently based in part on the fact that OSHA's manpower problems can produce considerable time lags between original and subsequent inspections; during this time the employer may remain in violation. Although it happens rarely in practice, this tenday limit can be waived in egregious circumstances. Id. For example, OSHA has embarked on a campaign to waive the limitation when sanctioning violators of its coke-oven emissions standard. 10 O.S.H. REP. (BNA) 461 (1980). Battles over the agency's attempts to enforce that standard have been taking place for years, as has continued widespread industry non-compliance.

74. 29 U.S.C. $\$ 662$ (1976).

75. 29 U.S.C. $\$ 662(b)$ (1976). See, e.g., Secretary v. Dye Constr. Co., 1971-1973 OSHD (CCH) II 15,720 (D.Colo. Mar. 23, 1973) (granting TRO); Secretary v. C. N. Flagg \& Co., No. 15,268 (D. Conn. Sept. 14, 1972) (granting TRO and preliminary injunction); Secretary v. Greenfield \& Assoc., 1 O.S.H. Cas. (BNA) 1015 (E.D. Mich. Jan. 5, 1972) (granting TRO and preliminary injunction). 76. One exception is Secretary v. A.G. Pinkston Co., 1971-1973 OSHD (CCH) I] 15,498 (E.D. Va. Dec. 20, 1972) (granting permanent injunction against trench-shoring violations at particular jobsite; no mention made of apparent interlocutory limitations of injunctions under 29 U.S.C. $\S$ 662(b) (1976)).

77. See, e.g., Brennan v. OSHRG and Kesler \& Sons Constr. Co., 513 F.2d 553 (10th Cir. 1975): Section 662 provides that under certain circumstances United States district courts may restrain employment conditions or practices which create such an imminent danger . . . that such danger could not be eliminated through the Act's other enforcement procedures. This 
surround the injunctive power often render it no more immediately useful than the enforcement procedures it was meant to shortcut. ${ }^{78}$ Unsurprisingly, the injunctive power has been invoked by OSHA only rarely, and with limited usefulness. ${ }^{79}$

\section{The Criteria by Which Violations are Categorized}

An evaluation of the effectiveness of OSHAct sanctions and remedies cannot focus solely on an examination of the maximum penalties available. The Act is pervaded by a relatively complex collection of criteria which determine how violations are categorized and sanctioned. The OSHAct not only provides OSHA with an inadequate range of administrative sanctions, but also stresses the wrong priorities in singling out particular violations as targets for extraordinary sanctions. The criteria focused upon here are the "willfulness" test of sections 666(a) and 666(e), the "repeated violation" standard of section 666(a), and the lethality test of section 666(e).

Several aspects of the OSHAct make these three criteria extremely important. As described, the sanctions available for violations outside of the three most seriously sanctioned categories are almost negligible. If a violation is not held to be "willful" or "repeated," the fine imposed cannot exceed $\$ 1000 ; ;^{80}$ if a willful violation does not result in the death of an employee, no criminal liability or attendant threat of incarceration

particular section, in our view, is designed to meet the situation in which, for example, immediate abatement is ordered, and the employer contests the citation. Then, if the danger be great and imminent, the Secretary may invoke the provisions of $\$ 662$ and go to court in an effort to get immediate corrective action.

Id. at 558; see also Whirlpool Corp. v. Marshall, 445 U.S. 1, 8-10 (1980) ("By means of a temporary restraining order or preliminary injunction, the court may . . . require the employer to avoid, correct, or remove the danger. . . \$662(a). Such an order may continue pending the consummation of the Act's normal enforcement proceedings. $\$ 662(\mathrm{~b})$." Id. at 9.)

A close reading of the language of the Act supports this narrow construction. See M. ROTHSTEIN, supra note 70, $\S 308$ (noting that TRO's are limited to five days under $\S 662(\mathrm{~b})$, rather than customary ten); Dellapenna, Emergency Injunctions Under OSHA, 8 ENVT'L. L. 723, 742-43 (1978); see also 116 CONG. REC. 37,338 (1970) (remarks of Senator Dominick); 116 CONG. REC. 37,624 (1970) (remarks of Senator Javits).

78. See Dellapenna, supra note 77, at 742-48. Only the Secretary of Labor is empowered to seck imminent-danger injunctions; employers and their unions are not. The Secretary's power is also undercut by the requirement that he seek an injunction in federal court, rather than simply by issuing an administrative order. But see id. at 744-46 (workers may be entitled to walk off the job without reprisals in "emergency situations"). See also Marshall v. Daniel Constr. Co., 563 F.2d 707, 713-15 (5th Cir. 1977) (exploring the scope of OSHA's emergency remedial powers).

79. Rothstein reports that as of 1977 , injunctions had been sought only nine times. Relief was granted in four of those cases, and denied in one; the other four cases resulted in consent agreements. M. ROTHSTEIN, supra note $70, \S 308$, at $319-20$ (no additional injunctions reported in 1982 pocket part).

80. See 29 U.S.C. $\$ 666($ a)-(c) (1976). Fines for failure to abate are an exception. See supra pp. 1460-61. 
arises. ${ }^{81}$ In addition, OSHA's chronically strained enforcement budget prevents the agency from imposing costly sanctions upon more than a small number of employers. ${ }^{82}$ Costly sanctions are far more likely to be legally contested than are smaller ones, and are more expensive for OSHA to impose. ${ }^{83}$ The group of violations singled out for higher sanctions should thus be carefully drawn, and should not be unnecessarily large.

\section{A. The Willfulness Standard}

The present structure of the Act places paramount importance upon the issue of whether a violation has been committed "willfully." This determination serves as a threshold test for the most seriously sanctioned class of civil OSHAct violations, and for all criminal violations. While the factors currently taken to comprise "willfulness" are not irrelevant to the determination of how severely a violation should be sanctioned, elevating corporate "willfulness" to its present central position has several undesirable consequences.

The first problem with the willfulness standard is that it focuses litigation on the convoluted issue of corporate state of mind. Establishing that a corporation has acted "willfully" saddles OSHA with what can be a highly problematic and expensive proof burden, especially under the standard for criminal convictions. ${ }^{84}$ Corporate willfulness is imputed from the acts and apparent knowledge of supervisory employees, and inferred through such evidentiary proxies as a history of prior citations and the length of time a violation has continued uncorrected.

The OSHRC, however, is already authorized to consider a variety of factors in determining appropriate penalties. These include "the gravity of

81. See 29 U.S.C. $\$ 666(e)(1976)$.

82. On OSHA's overwhelming caseload backlog, see Rothstein, supra note 5, at 115-18. On inadequate inspection levels, see supra note 41.

83. Violations involving high penalties and high abatement costs are far more likely to be appealed than are other citations. See Rothstein, Judicial Review of Decisions of the Occupational Safety and Health Review Commission-1973-1978: An Empirical Study, 56 CHI.-KENT L. REV. 607, 610-14 (1980) (empirical examination of the nature and outcome of OSHAct cases before the OSHRC and federal courts of appeals).

84. Numerous cases attest to the burden imposed on OSHA in establishing "willfulness." See, e.g., Secretary v. Favrot-Bellows, Inc., 6 O.S.H. Cas. (BNA) 1531 (OSHRC 1978) (where failure to install guardrails or issue safety belts to workers on 11 th floor scaffolding resulted in fatal fall, foreseeability of the danger held to qualify the violation as "serious" but not "willful;" penalty reduced from \$10,000 to \$500); Secretary v. Dye Constr. Co., 4 O.S.H. Cas. (BNA) 1444 (OSHRC 1976) (insufficient evidence to establish willfulness, despite employer's previous conviction for fatal criminal violation of same standard, see supra note 17).

On confusion in the federal courts surrounding the construction of "willfulness," see infra note 88. In particular, OSHA continues to be reversed in the Third Circuit on willful violations, due to that court's distinctively stringent definition of willfulness. See Babcock \& Wilcox Co. v. OSHRC, 622 F.2d 1160, 1165 (3rd Cir. 1980) (violations held not "willful" because not caused by "deliberate or intentional disregard of the statute"). 
the violation, the good faith of the employer, and the history of previous violations." ${ }^{\text {"8s }}$ On judicial review, the OSHRC's determinations on these matters are conclusive so long as they are "supported by substantial evidence." 186 Were the various proxies which are currently bundled into a single legal burden of "willfulness" instead left to the administrative judgments of OSHA and the OSHRC, a time-consuming and expensive issue would be removed from OSHAct trials. ${ }^{87}$

A further problem with the OSHAct's use of the "willfulness" standard is that it focuses not on the injury sustained by the worker, but on the employer's "state of mind" and moral culpability. ${ }^{88}$ The limited usefulness of the concepts of corporate scienter and moral culpability, discussed above in reference to the use of the criminal sanction, ${ }^{89}$ persists whether a willfulness standard is employed in a criminal or a putatively civil sanction. ${ }^{90}$ Admittedly, the sanctioning of moral culpability was not Congress' sole, nor even overriding, purpose in drafting the OSHAct. ${ }^{11}$ Insofar as the Act

85. 29 U.S.C. $\$ 666($ i) (1976).

86. 29 U.S.C. $\$ 660($ a) (1976). See, e.g., Long Mfg. Co., N.C. v. OSHRC, 554 F.2d 903 (8th Cir. 1977):

As to the amount of the penalty assessed, we have recognized that a determination of how large or how small a penalty should be imposed is not a finding of fact but is an exercise of discretion by the Commission which will not be disturbed by us in the absence of abuse.

Id. at 908 (citations omitted).

87. Given the paramount significance currently attached to willfulness, procedural changes so dramatically lowering OSHA's proof burden might seem startling. Under the proposals put forth in the final section of this Note, however, "willfulness" would hold no such position of centrality.

88. The degree of bad faith necessary to constitute "willfulness" under the OSHAct, and under corporate regulatory acts in general, is open to debate. See Sheahan, supra note 16, at 333-39. The Third Circuit has applied a relatively stringent construction:

Willfulness connotes defiance or such reckless disregard of consequences as to be equivalent to a knowing, conscious, and deliberate flaunting of the Act. Willfulness means more than merely voluntary action or omission-it involves an element of obstinate refusal to comply.

Frank Irey, Jr., Inc. v. OSHRC, 519 F.2d 1200, 1207 (3rd Cir. 1974), aff', 519 F.2d 1215, 1219 (3rd Cir. 1975) (en banc), aff'd on other grounds sub nom. Atlas Roofing Co. v. OSHRC, 430 U.S. 442 (1977). A more typical construction is found in the Fourth Circuit's opinion in Intercounty Constr. Co. v. OSHRC, 522 F.2d 777, 779-80 (4th Cir. 1975) (" '[W]illful' means action taken knowledgeably by one subject to the statutory provisions in disregard of the action's legality. No showing of malicious intent is necessary."), cert. denied, 423 U.S. 1072 (1976). But see Cedar Constr. Co. v. OSHRC, 587 F.2d 1303, 1305 (D.C. Cir. 1978) ("While there may be a difference in emphasis in the Third Circuit's approach, we do not see that it rises to the level of a 'conflict' among the Circuits. ....")

89. See supra p. 1453.

90. The use of civil sanctions to punish morally culpable behavior also renders OSHAct sanctions vulnerable to attack for being, in effect, criminal sanctions. Sce Levin, supra note 16. Levin focuses on the unsuccessful constitutional challenges brought against civil OSHAct sanctions in Frank Irey, Jr., Inc. v. OSHRC, 519 F.2d 1200 (3rd Cir. 1974), affd, 519 F.2d 1215 (3rd Cir. 1975) (en banc), aff'd on other grounds sub nom. Atlas Roofing Co. v. OSHRC, 430 U.S. 442 (1977); and in Atlas Roofing Co. v. OSHRC, 518 F.2d 990 (5th Cir. 1975) (applying factors articulated in Kennedy v. MendozaMartinez, 372 U.S. 144 (1963), supra note 34), aff'd on other grounds, 430 U.S. 442 (1977).

91. This conclusion can be drawn from the reliance of the Act on an overwhelmingly civil enforcement scheme, as well as the ambit of the Act as a whole. Sec, e.g., S. REP. No. 1282, 91st Cong., 2d Sess., reprinted in 1970 U.S. CODE CONG. \& AD. NEWS 5177, 5177-81. The Senate Report describes the general reduction of workplace injuries and illnesses as the Act's central purpose: "The bill 
is primarily intended to protect the safety and health of workers, however, violations should be categorized according to criteria more directly related to the benefit of workers, such as either the actual infliction of any injury, ${ }^{92}$ or an employer history of recidivism.

\section{B. The Repeated Violation Standard}

In establishing the most strongly sanctioned category of civil violations, section 666(a) encompasses not only "willful" violations, but also "repeated" violations. ${ }^{93}$ The repeated violation standard might seem to address employer recidivism generally. ${ }^{94}$ The standard contains limitations, however, which render it inapt as a device for identifying and sanctioning recidivists.

First, the test is not satisfied by a general pattern of repeated violation, but encompasses only repeated violations of a particular OSHA standard. The OSHRC and the courts also have read the test to require that, in order to be categorized as "repeated," violations must be committed under substantially similar circumstances. ${ }^{95}$ These requirements are based largely on a view that the test is meant to single out employers that have

would achieve its purpose through programs of research, education and training, and through the development and administration . . . of uniformly applied occupational safety and health standards." Id. at 5177 . The Senate Report then reviews the toll exacted nationally by workplace injuries and illnesses, and the role that occupational safety and health legislation can and reportedly has played in spurring workplace protection.

In submitting the Conference Committee Report on the floor of the House, Rep. Daniels remarked: [I]n conference it was resolved that the only criminal penalties would be for a willful viola-

tion ... resulting in the death of an employee.

The conference report presented to this body today emphasizes the preventative rather than

the punitive aspect of job safety regulation. . . . [T] he legislation includes excellent provisions

for research into health hazards, for monitoring pollutant levels, [and] for a national institute

for occupational safety and health. . . .

116 CONG. REC. 42,203 (1970).

See also Atlas Roofing Co. v. OSHRC, 518 F.2d 990, 1010-11 (5th Cir. 1975), affd, 430 U.S. 442 (1977) (holding that courts must defer to Congress' characterization of Act's purposes as "remedial," barring convincing contrary evidence).

92. Smith has suggested abolishing the OSHAct's approach of mandatory safety standards in favor of an "injury tax." He concedes, however, that the approach is not helpful in the enforcement of workplace health standards. He also seems to ignore the incentives such a system would create for employers to suppress information about the occurrence of accidents. See R. SMITH, supra note 58, 78-83; Smith, The Feasibility of an "Injury Tax" Approach to Occupational Safety, 38 LAW \& CONTEMP. PROBS. 730 (1974) (economic analysis concluding that tax would have to be very large to have even moderate effect).

93. 29 U.S.C. $\$ 666(a)(1976)$ (subjects employers that "willfully or repeatedly" commit violations to $\$ 10,000$ civil liability).

94. See infra pp. 1469-70.

95. See, e.g., Secretary v. Potlatch Corp., 7 O.S.H. Cas. (BNA) 1061, 1062-64 (OSHRC 1978) (acknowledging diverse constructions of "repeated violation" and promulgating definitional "principles"); Secretary v. Smith Masonry Contractors, 6 O.S.H. Cas. (BNA) 1271, 1273 (OSHRC 1978) (upholding administrative law judge's finding of "repeated" violation, but with leave to allow employer to show violations occurred under different supervisors). For a general discussion of the various strictures surrounding the definition of a repeated violation, see M. ROTHSTEIN, supra note $70, \S 304$. 
been placed on notice, by a previous citation, that a specific condition is to be eradicated. Indeed, some courts have gone so far as to infer, from the common treatment in section 666(a) of "willful or repeated violations," that the "repeated" test is meant to include an implied state-of-mind requirement akin to willfulness."

The "repeated" standard, so far as it goes, is a useful one. It does not, however, represent a general recidivism standard. The various limitations placed on it retain overtones of moral culpability, i.e. of singling out employers that have violated standards intentionally or in deliberate disregard of their OSHA duties. A more generalized recidivism standard could dispense with the state-of-mind emphasis, and focus on a history of repeated violation simply as an indicator that an employer is not responding to OSHAct deterrents, and is likely to commit additional violations in the future.

It should also be noted that while the current standard does subject repeat violators to higher penalties, it does so only in the form of larger post-hoc fines. Where the employer's previous violations have been "willful," the situation is even worse, since the "repeated" label then triggers no increased liability whatever. ${ }^{97}$ Given that the population of repeat violators is by definition resistent to normal OSHAct deterrents, and given the extremely low inspection rates realized by OSHA, ${ }^{98}$ this continued exclusive use of simple post-hoc fines is hardly calculated to enhance compliance. At no point, however, does a repeated violation trigger the obvious remedial response: emphasis on legally coerced specific rehabilitation. ${ }^{99}$

96. The Court of Appeals for the Third Gircuit, for example, has stood steadfastly by its construction of "repeated," articulated at length in Bethlehem Steel Corp. v. OSHRC, 540 F.2d 157, 160-62 (3rd Cir. 1976); see, e.g., Jones \& Laughlin Steel Corp. v. Marshall, 636 F.2d 32, 33 (3rd Cir. 1980):

In Bethlehem Steel we declared that two violations of a safety standard could not form the basis of a citation for a "repeated" violation; rather, we held that several instances indicating a flouting of OSHA standards were necessary to establish a predicate for a finding of repeated violations.

Id. at 33. The OSHRC has also been attracted, at times, to a state-of-mind requirement for repeated violations; see, e.g., Secretary v. George Hyman Constr. Co., 5 O.S.H. Cas. (BNA) 1318 (OHSRC 1977) (three-way split among the three commissioners in defining "repeatedly," so no official action taken). OSHA, on the other hand, takes the position that there is no state-of-mind element to a repeated violation; see OSHA FIELD OPERATIONS MANUAL, Ch. VIII(B)(5)(b), reprinted in O.S.H. Rep. (BNA), Ref. File 77:3108 ("Repeated violations differ from willful violations in that they may result from an inadvertent, accidental or ordinarily negligent act." (emphasis in original)). For a more detailed discussion, see M. RoTHSTEIN, supra note 70, $\$ 304$ at 305-07 \& Supp. 1982.

97. Repeated willful violations are subject to no greater liability under 29 U.S.C. $\$ 666$ (a) (1976) than isolated willful violations, although the OSHRC may in its discretion consider the history of previous citations in setting fines. 29 U.S.C. $\$ 666(i)$ (1976).

98. See supra note 41 .

99. See, e.g., infra p. 1470. 


\section{The Lethality Standard}

Like the other OSHAct criteria, the requirement that a violation have a fatal consequence in order to be categorized as criminal has several untoward effects. ${ }^{100}$ The most significant consequences of the lethality test are manifested in the context of "health," as opposed to "safety," violations. ${ }^{101}$ The lethality test fails to encompass virtually any health violations. Widespread exposure of workers to particulate and chemical emissions is certainly one of the most serious threats to worker life and health, and was recognized as such by the drafters of the Act. ${ }^{102}$ Proving a direct chain of causation between such exposure and any particular death, however, is nearly impossible for most emissions. ${ }^{103}$ The necessity of proving such causation to the satisfaction of the criminal burden of proof is virtually insurmountable. Furthermore, some workplace toxins commonly induce such maladies as sterility, paralysis, or fetal deformities, while only rarely causing the death of a worker. ${ }^{104}$ Other toxins, while ultimately lethal, have

100. In pertinent part, 29 U.S.C. $§ 666(e)$ (1976) reads:

Any employer who willfully violates any standard, rule, or order, . . . and that violation caused death to any employee, shall, upon conviction, be punished by a fine of not more than

$\$ 10,000$ or by imprisonment for not more than six months, or by both. . . . (emphasis supplied).

101. "Health" violations are defined in S. REP. NO. 1282, 91st Cong., 2d Sess., reprinted in 1970 U.S. CODE CONG. \& AD. NEWS 5177, 5177-79. Health violations are defined as those leading to the possibility of occupational diseases such as "cancer, respiratory ailments, allergies, heart disease, and others." Id. at 5178. Usually they are associated with exposure to toxic substances, but they also include "harmful physical agents, such as severe noise or vibration." Id. at 5179.

102. See S. REP. NO. 1282, 91st Cong., 2d Sess., reprinted in U.S. CODE CONG. \& AD. NEWS 5177, 5178-81.

The Bureau of Labor Statistics reported that 4950 workers (at establishments with more than ten workers) suffered work-related death in 1979. Presumably because of causative uncertainty, however, the Bureau's statistics virtually ignore occupational diseases as a cause of death. The business of estimating the number of deaths caused annually by occupational disease is extremely unreliable. A survey of various estimates is contained in P. BARTH \& H. HUNT, WORKERS' COMPENSATION AND WORK-RELATED ILLNESSES AND DISEASES 15-27 (1980). According to Barth and Hunt, the most publicized figure is the estimate of 100,000 deaths per year contained in the PRESIDENT'S REPORT ON OCCUPATIONAL SAFETY AND HEALTH (1972), but some estimates range as low as 10,000 deaths per year.

The Carter administration was strongly committed to shifting OSHA's enforcement priorities toward occupational health concerns. According to Berger and Riskin, supra note 60, Dr. Eula Bingham, Assistant Secretary of Labor for Occupational Safety and Health in the Carter administration, "was selected for the post largely because of her professional concentration in occupational cancer and other diseases." Id. at 286 n.6. Heavy emphasis was also placed on increasing the number and training of occupational health inspectors. Id. at 285-86.

103. The limits of current scientific understanding of carcinogenesis is one factor, as is the hostility of the courts to statistical evidence of the probability that a specific cancer was caused by a particular exposure. See Note, Tort Actions for Cancer: Deterrence, Compensation, and Environmental Carcinogenesis, 90 YALE L.J. 840, 847-855 (1981).

104. It might be argued that however poignant these health effects may be, they are less significant than fatalities. While such an argument may be reasonable in a sense, it hardly justifies the Act's failure to recognize such health effects as significant. Under the Act, even repeated exposure of workers to such maladies subjects the employer only to $\$ 10,000$ civil liability under 29 U.S.C. $\$ 666(a)$ (1976). 
latency periods of up to forty years, periods far in excess of the statute of limitations for OSHAct violations. ${ }^{105}$ Under the lethality test, employers illegally exposing workers to such substances are assured of never being charged criminally under the OSHAct for such violations.

An additional problem with the lethality test derives from the fact that it hinges criminality on the occurrence of a result, rather than merely on the commission of a violation. Any employer exposing its workers to a substantial chance of death is by definition guilty of a "serious violation." 106 The imposition of enhanced liability on those employers that actually kill workers is presumably justified as additionally deterring all employers from life-endangering behavior. ${ }^{107}$ As described above, however, being sanctioned criminally is an exceedingly unlikely prospect even if a violation does have fatal consequences. ${ }^{108} \mathrm{~A}$ profit-maximizing employer contemplating whether to illegally risk the lives of its employees can discount the deterrent effect of criminal OSHAct penalties not only by the employer's chance of escaping conviction if a worker is killed, but also by the chance that a particular violation will not in fact cause a death. In light of the limited severity of criminal OSHAct penalties, and of OSHA's inability to impose a preventative safety program, such double discounting is unsound statutory policy.

\section{Proposals}

The shortcomings of the current OSHAct spring not from any single inadequacy, but from an interrelated collection of flaws. The effectiveness of the Act would be significantly improved by the implementation of the following proposals. The proposals are first outlined in their entirety, and then followed by a discussion of their merits.

105. See generally P. BARTH \& H. HUNT, supra note 102, at 114-25.

106. Under 29 U.S.C. $\$ 666(j)(1976)$ a serious violation exists if "there is a substantial probability that death or serious physical harm could result from a condition which exists . . . in such place of employment unless the employer did not, and could not with the exercise of reasonable diligence, know of the presence of the violation." It is of course conceivable that a violation could cause a death even though there existed no substantial probability of such a mishap, but prosecution under such circumstances is unlikely at best.

107. Such arguments are traditionally associated with tort law. See G. CALABRESI, THE COSTS OF ACcIDENTS 69-75 (1970). Because the OSHAct violation itself is an unlawful act, however, a more apt analogy is to criminal law, wherein result-orientation is relatively common. The result of an illegal act distinguishes crimes of attempt, for example, and separates manslaughter from reckless endangerment. See generally MODEL PENAL CODE $\$ 2.03$ (Proposed Official Draft 1962) ("Causal Relationship Between Conduct and Result; Divergence between Result Designed or Contemplated and Actual Result or Between Probable and Actual Result").

108. See supra p. 1450 (many such violations are cited civilly); supra note 42 (most cases referred to Washington for prosecution are ultimately not prosecuted); see also supra note 27 (additional screening function performed by the Justice Department). 


\section{A. Proposed Statutory Changes}

The first proposal is that the use of the criminal law as embodied in section 666(e) of the Act be abandoned. Its role as OSHA's "teeth" should be filled in its stead by an augmented system of civil sanctions and remedies. Civil fines under the OSHAct should not only be dramatically increased, ${ }^{109}$ but should also be supplemented by giving OSHA meaningful coercive and rehabilitative power-in the form of authority to issue broad cease-and-desist orders against recidivous violators, and to impose prospective safety and monitoring programs. Unlike OSHA's current injunctive powers under section 662, the proposed capabilities would be neither interlocutory nor dependent upon the presence of "immediate" or "imminent" danger. ${ }^{110}$

As to the criteria for categorizing violations, both the lethality test and the "willfulness" standards should be dispensed with. The current distinction between "serious" and "non-serious" violations should be retained."1 It should be accompanied, however, by only one other statutory standard for classifying violations: the repeated commission by an employer of serious violations. While this standard is akin to the extant "repeated" standard, ${ }^{112}$ it is significantly broader. "Repeated" should not require repetitive violations of a single OSHA standard, but should be taken to indicate inordinate general recidivism, i.e. a particularly high rate of any serious OSHA violations would qualify an employer as a repeater. ${ }^{13}$ The proposed "repeated" standard would delineate the only category of violation to be statutorily identified as subject to extraordinary remedies. ${ }^{14}$ All other "serious" violations, whether or not they are committed "willfully," and whether or not they have deadly results, should be treated as a single

109. See supra note 58.

110. Some form of procedurally streamlined emergency powers should be available, but they should not be subject to the limitations of current "imminent danger" powers. Abatement powers, which are considerably narrower in scope and application than the proposed powers, should be retained; they perform the useful, if limited, function of forcing the correction of ongoing violations. Like simple civil citations for other violations, however, fines associated with the abatement power should be substantially increased.

111. 29 U.S.C. § 666(j) (1976). See supra P. 1447.

112. 29 U.S.C. \$ 666(a) (1976).

113. The concern that an employer be put on notice of its heightened liability is a consideration often voiced by the OSHRC when confining the definition of "repeated" violations to substantially similar violations of the same standard. See supra pp. 1465-66. However, a general recidivism standard would not sacrifice the serving of "notice." The employer that begins to establish a poor record has notice that it must pay greater attention to OSHA standards in general. Given that all employers have a legal duty to heed both particular OSHA standards and the "general duty clause," infra note 118 , such generalized accountability is not an untoward burden.

114. The definition of a recidivist would of course have to include considerations of the size of the employer, the general rate of violation in its industry, and the nature of its violations. The "good faith of the employer," currently given equal statutory status with these other considerations relevant to the fixing of penalties, 29 U.S.C. $\$ 666(\mathrm{i})$ (1976), is not of central concern. The measures proposed are not meant to punish culpability, but to curb unacceptable behavior. 


\section{class of violations. ${ }^{115}$}

Once a particular employer has been identified as a recidivist, OSHA should be empowered to fashion broad remedial measures, and to impose those measures through administrative orders. Such orders would be backed up by the threat, in the event that they are disobeyed, of civil and criminal contempt charges against specific identified corporate officers. ${ }^{116}$ Such powers should also be flexible, encompassing the authority to impose safety programs $\mathrm{s}^{117}$ on recidivist employers that surpass the duties imposed on non-recidivist employers by ordinary OSHA standards and the "general duty clause." 118 Where possible, such programs should be enforced through reporting requirements. If such reports would be either impracticable or ineffective, as where violations are transient or subject to misrepresentation, ${ }^{119}$ an OSHA safety inspector could be assigned to that employer, on a full-time or part-time basis, at the employer's expense. ${ }^{120}$

115. Considerations currently related to "willfulness," such as duration of violation and employer awareness, can be included among those various factors that the OSHRC is to consider in setting fines. Where the OSHRC's judgment on such factors is "supported by substantial evidence," however, the courts would be obliged to defer to that judgment. See supra p. 1464 (description of the OHSRC's discretion in setting penalties).

116. Under 29 U.S.C. $\$ 660$ (b) (1976), any "final order" of the OSHRC, including any uncontested order by OSHA, can be enforced by a decree from the clerk of any federal court of appeals. Such decrees are enforceable by the courts through the threat of contempt proceedings.

117. The sweeping powers of the NLRB to prevent unfair labor practices are a useful analogy here. The Board is empowered to:

issue and cause to be served on [the person committing the unfair labor practice] an order requiring such person to cease and desist from such unfair labor practice, and to take such affirmative action . . . as will effectuate the policies of this Act. . . .

29 U.S.C. $\$ 160$ (c) (1976). As construed by the Supreme Court:

[t] he Board's power is a broad discretionary one, subject to limited judicial review. . . The Board's order will not be disturbed 'unless it can be shown that the order is a patent attempt to achieve ends other than those which can fairly be said to effectuate the policies of the Act.'

Fibreboard Paper Products Corp. v. NLRB, 379 U.S. 203, 216 (1964) (case citations omitted).

Of particular interest here are the Board's powers against recidivists, and against "like or related" practices:

Without doubt the Board has a duty in a litigated case to employ broader and more stringent remedies against a recidivist than those usually invoked against a first offender, particularly where normal remedies have proved to be ineffective after earlier proceedings.

Container Systems Corp. v. NLRB, 521 F.2d 1166, 1171 (2d Cir. 1975). See also supra note 32 (discussing NLRB's broad power to prohibit future violations by recidivist unions, even against nonparty employers).

118. The employer's present duties are described in 29 U.S.C. $\S 654$ (1976). Section 654(a), the so-called "general duty clause," requires that, "[e]ach employer shall furnish to each of his employees employment and a place of employment which are free from recognized hazards that are causing or are likely to cause death or serious physical harm."

119. For example, trench-sloping violations are too ephemeral to be reliably monitored through written reports, as are violations relating to employee behavior near high-tension lines, on scaffolding, or in other risky circumstances. Orders requiring broad engineering controls, however, such as those directed at most airborne contaminants, could be monitored through written reports and only an occasional verification inspection.

120. Given the historically low rate of OSHA inspections, supra note 41 , the preventative and coercive effect of such safety programs would be undermined if findings of non-compliance were dependent on normal inspection and citation procedures. While the powers proposed may seem potentially burdensome, it should be noted that they are reserved only for a small group of employers that 


\section{B. Comparative Analysis}

The proposals advanced here arise primarily from the conclusion that the present scheme of OSHAct sanctions and remedies does not work, and cannot be made to function effectively without significant statutory changes. In advocating alternative methods for enforcing the OSHAct, these proposals also point toward changes in policy aims. The primary basis for selecting violators to be sanctioned extraordinarily, for example, is shifted from willfulness to recidivism. In choosing remedies, harm-based post-hoc fines are de-emphasized in favor of specific prospective orders. As to more general aims, the pursuit of retribution is downplayed in the interest of more effective deterrence and rehabilitation. Both policy arguments and feasibility considerations underlie the advocacy of these shifts. The intention is to direct OSHAct enforcement toward goals which are more realistic, as well as calculated more adequately to insure safe workplaces; and to empower OSHA with regulatory tools capable of achieving those goals.

The proposals advanced sacrifice none of the existing deterrent capability of the OSHAct's civil sanctions and in fact provide additional deterrents. Unlike a simple abatement order, a broad safety and monitoring program triggered by repeated violations may impose otherwise avoidable expenses on an offending employer. ${ }^{21}$ In instances in which a recidivist employer has reason to fear the implementation of such a program, those threatened expenses represent an additional deterrent to violation. The procedural ease, relative to a criminal conviction, with which such an administratively ordered safety program could be imposed also adds to the reliability and likelihood of sanctioning, and so to deterrence. ${ }^{122}$

have shown themselves to be inordinately unresponsive to OSHA's ordinary enforcement deterrents.

121. An abatement order carries no deterrent threat, since it is basically no more than an order to comply with the employer's responsibilities under the Act. The safety programs described here would impose particular burdens on the cited employer. Primarily those would be the costs associated with satisfying OSHA that the employer was actually in compliance. However, OSHA might conclude that particularly high standards for a specific employer were necessary to achieve acceptable safety levels, as where an employer had repeatedly expressed hostility to the general purposes of the Act. Under the proposals herein, such a remedy could be invoked.

122. It could be argued that the dysfunction of the OSHAct criminal sanction has not been absolute, as indicated by the handful of convictions discussed supra pp. 1448-50; and that so long as the criminal sanction is not totally useless, the introduction into the Act of cease-and-desist orders need not be accompanied by the eradication of criminal penalties. Whether the criminal sanction has been totally useless, however, is an open question. Except for the supposed stigma associated with criminal conviction of a corporation, see supra note 39 (discounting any distinctive value to such stigmatic effect), only two criminal convictions have produced penalties not commonly handed out for civil violations. United States v. Hughey Constr. Corp., Cr. No. 81-16D (W.D. Okla. Feb. 27, 1982); United States v. Crosby \& Overton, No. CR-74-1832-F (C.D. Cal. 1975); see supra p. 1449. Even in those cases, the extraordinary sanction was not incarceration but probation. Most of the rehabilitative and deterrent effect of probation, however, would be adequately served by the prospective administrative orders outlined here.

More importantly, the pursuit of criminal sanctions comes at a high cost in terms of both adminis- 
The more central contribution of these proposals is their emphasis on specific rehabilitation. Whether deliberately or through inadvertence, some employers show themselves to be particularly unresponsive to the deterrents of OSHA enforcement. ${ }^{123}$ When an employer has so distinguished itself, the emphasis of enforcement should shift from generalized deterrence to specific coercive rehabilitation and prevention. Giving OSHA the power to issue permanent cease-and-desist orders and to impose comprehensive safety programs on repeat violators would give the agency the tools necessary to pursue such aims. The threat of contempt charges to effectuate these orders would circumvent problems associated with the threat of individual criminal liability, such as jury reluctance to convict and general issues of fairness, ${ }^{124}$ while still focusing responsibility on particular corporate officers.

Narrowing the population upon which these remedies are to be focused also offers enforcement advantages. A focus on recidivism foregoes the emphasis on moral culpability inherent in a willfulness test in favor of a standard which looks directly to the threat to workers posed by a particular employer. The employer that repeatedly commits serious violations of the OSHAct, whether willfully or negligently or otherwise, is not re-

trative resources, and ease and predictability of enforcement-a cost justifiable only if criminal sanctions offer some clear benefit. The resources devoted to the twelve cases so far prosecuted, see supra note 17, and the forty-eight cases referred in the last two years for possible prosecution, see supra note 42, would have been better spent pursuing remedial safety programs, or even civil fines, against a larger number of employers.

Furthermore, the continued existence of an unused criminal sanction "on the books" would sustain the illusion that the OSHAct is backed up by the "teeth" of an extraordinary sanction. Neither workers nor policymakers ought to be so misled as to the extent of protection the Act genuinely makes available.

123. See, e.g., United States v. Dye Constr. Co., No. 73-CR-417 (D. Colo 1974), aff', 510 F.2d 78 (10th Cir. 1975); Levin reports that Dye had been cited for failure to shore its trenches eleven times and had had jobs closed as "imminent dangers" six times in the nine months preceding the fatality that triggered criminal liability. Levin, supra note 17 , at 735 . Since that criminal conviction, Dye Construction has continued to be cited repeatedly. See, e.g., Secretary v. Dye Constr. Co., 6 O.S.H. Cas. (BNA) 1685 (OSHRC 1978) (failure to shore trenches); Secretary v. Dye Constr. Co., 9 O.S.H. Cas. (BNA) 1215 (OSHRC 1980) (worker seriously injured by improperly secured 5000 pound drain cover falling from lift; penalty of $\$ 280$ for four serious violations). In Empire-Detroit Steel Div., Detroit Steel Corp. v. OSHRC, 579 F.2d 378 (6th Cir. 1978), defendant had been involved in an extended series of violations over a period of more than two years. Steam explosions in the employer's steel-making facility, caused by the accumulation of large puddles of coolant water near slag furnaces, killed a worker in June 1972. After a number of citations for "repeated violations," a pair of additional explosions in September 1974 injured ten workers. The employer was fined $\$ 10,000$ for a willful violation.

OSHA's Compliance Activity Reports are not helpful in providing statistical evidence of recidivism, because they do not distinguish between willful and repeated violations. See Rothstein, supra note 5, at 98 n.164 (providing multi-year table (1973-80) of violations charged by OSHA, by degree, based on Compliance Activity Reports). Some partial evidence of the extent of recidivism is provided by the ten to twenty cases annually in which a cited employer contests the "repeated" nature of its citation. Such cases are catalogued each year under classifications 115.051 et seq. in the Cumulative Digest \& Index of OCCUPATIONAL SAFETY AND HEALTH CASES (BNA).

124. See supra pp. 1455-56. 


\section{OSHA}

sponding to the deterrent threats of the Act. It is logically that group of . employers that must be subjected to some remedy other than bare deterrence. The current treatment of "repeated violations" in the Act fails to tailor the remedial response to the selected population, merely pushing the repeat violator into a more stiffly fined category. In recognition of these employers' unresponsiveness to the Act's deterrents, this Note proposes that the Act address recidivism directly, through an individualized compliance and monitoring program.

\section{Conclusion}

Violations that are currently subject to the strongest sanctions under the OSHAct are identified as 1) those in which the employer acts "willfully"; 2) those that represent repeated violations of the same standard under similar circumstances; and 3) "willful" violations that cause the death of an employee. Under the OSHAct, an inflexible and relatively weak set of civil sanctions and remedies is supposedly backed up by the threat of criminal sanctions. The criminal sanction under the OSHAct has not only been singularly unsuccessful, but has also been employed in pursuit of goals of questionable value. Punishing an employer on the basis of moral culpability is neither directly beneficial to workers nor, where the defendant is a corporation, an achievable goal. While individual criminal liability for corporate officers may circumvent some of the difficulties associated with imposing corporate criminal liability, convictions of individuals are extremely elusive, and deterrence suffers accordingly.

In the absence of a credible or useful threat of criminal sanctions, OSHA's civil powers are far too restricted to effect the policies of the Act. This Note proposes supplanting the OSHAct's emphasis on post-hoc fines with sweeping prospective remedial powers. An employer's recidivism, rather than an employee death or the employer's "state of mind," would subject a violator to these extraordinary remedies, since by its recidivism an employer will have shown itself to be inadequately responsive to the ordinary deterrents of the Act. The proposed remedial powers focus on the prospective rehabilitation of a selected population of offenders, favoring the prevention of future harm over the punishment of past acts. 